\title{
Modifications of bacterial cellulose in wound care
}

\section{Modyfikacje bakteryjnej celulozy do stosowania w opatrywaniu ran}

\author{
Justyna Paleczny ${ }^{A, D}$, Malwina Brożyna ${ }^{C, D}$, Adam Junka ${ }^{E}$, Marzenna Bartoszewicz, Ruth Dudek-Wicher ${ }^{\mathrm{B}}$ \\ Department of Pharmaceutical Microbiology and Parasitology, Faculty of Pharmacy, Wroclaw Medical University, Poland \\ A - research concept and design; $\mathrm{B}$ - collection and/or assembly of data; $\mathrm{C}$ - data analysis and interpretation; \\ $D$ - writing the article; $E$ - critical revision of the article; $F$ - final approval of the article
}

Polymers in Medicine, ISSN 0370-0747 (print), ISSN 2451-2699 (online)

Polim Med. 2021;51(2):77-84

Address for correspondence

Ruth Dudek-Wicher

E-mail:r.dudek.wicher@gmail.com

Funding sources

This research was funded by grant for Young Scientists No. STM.D230.20.127 and Wroclaw Medical University statutory funding No. SUB.D230.21.102.

Conflict of interest

None declared

Received on August 24, 2021

Reviewed on October 7, 2021

Accepted on October 25, 2021

Published online on November 12, 2021

\section{Cite as}

Paleczny J, Brożyna M, Junka A, Bartoszewicz M, Dudek-Wicher R. Modifications of bacterial cellulose in wound care. Polim Med. 2021;51(2):77-84. doi:10.17219/pim/143330

DOI

10.17219/pim/143330

Copyright

( 2021 by Wroclaw Medical University This is an article distributed under the terms of the Creative Commons Attribution 3.0 Unported (CC BY 3.0) (https://creativecommons.org/licenses/by/3.0/)

\begin{abstract}
Wound infection may occur in acute and chronic wounds, wounds resulting from surgery or traffic accidents, and burns. Regardless of the extent and cause of the wound, prompt treatment is essential in reducing the patient's pain and limiting the spread of contamination. Improper wound care and associated chronic diseases may hinder the therapeutic success. Bacterial cellulose (BC) is highly biocompatible and has no cytotoxic effect on cells engaged in wound healing, such as fibroblasts and keratinocytes. Its high hydration level guarantees the maintenance of a moist wound environment. High mechanical strength, flexibility and resistance to damage make BC a promising material for dressings. Unfortunately, it does not display an inhibitory effect on bacterial growth. Introducing antimicrobial agents into the structure of $B C$ has been a subject of many studies. This paper aims to present the latest reports on the possibility of the absorption of bacteriostatic and bactericidal agents in BC, such as metal particles, essential oils, antibiotics, antiseptics, and wound irrigation solutions. Moreover, the modifications in $\mathrm{BC}$ culture and post-production treatments in order to improve its physical properties are discussed.
\end{abstract}

Key words: wound infection, wound, antisepsis, cellulose, biological dressings

\section{Streszczenie}

Infekcja może rozwijać się w ranach ostrych, przewlekłych, powstałych na skutek operacji, wypadków komunikacyjnych czy oparzeń. Niezależnie od rozległości ran i przyczyn ich powstania konieczne jest szybkie zastosowanie odpowiedniego leczenia, celem zmniejszenia doznań bólowych pacjenta oraz ograniczenia rozprzestrzeniania się infekcji. Choroby towarzyszące oraz niewłaściwa pielęgnacja ran mogą przyczyniać się do opóźnienia sukcesu terapeutycznego. Celuloza bakteryjna charakteryzuje się dużą biozgodnością oraz nie wykazuje działania cytotoksycznego względem komórek odpowiedzialnych za proces gojenia, takich jak fibroblasty i keratynocyty. Jej wysokie uwodnienie zapewnia utrzymanie wilgotnego środowiska rany. Wytrzymałość mechaniczna, elastyczność i odporność na uszkodzenia to cechy, dzięki którym celuloza bakteryjna rozważana jest jako potencjalny materiał do produkcji opatrunków. Niestety, bakteryjna celuloza nie wykazuje działania hamującego wzrost bakterii. Trwają badania nad możliwością wprowadzenia środków przeciwdrobnoustrojowych do struktury bakteryjnej celulozy. Celem pracy jest omówienie najnowszych doniesień dotyczących możliwości absorpcji środków bakteriostatycznych i bakteriobójczych w bakteryjnej celulozie, takich jak cząsteczki metali, olejki eteryczne, antybiotyki, antyseptyki oraz środki do przemywania ran. W niniejszej pracy omówiono również modyfikacje warunków hodowli bakteryjnej celulozy oraz zabiegi poprodukcyjne mające na celu ulepszenie właściwości fizycznych celulozy bakteryjnej.

Słowa kluczowe: zakażenia ran, rany, antyseptyka, celuloza, opatrunek biologiczny 


\section{Introduction}

The skin functions as a protective barrier against pathogens, physical injury, ultraviolet radiation, and chemicals. It also regulates the body temperature and prevents excessive water loss and desiccation. Disruption of skin integrity, caused by burns, trauma, diabetes, and venous or pressure ulcers, leads to the impairment of its essential functions and can result in hard-to-heal wounds. The risk of developing chronic wounds increases in people with diabetes and obesity, as well as in elderly patients. Severe tissue damage with an infectious process is often difficult to control. It may result in an amputation or a life-threatening injury. ${ }^{1}$ The treatment is a long, multistep process, involving wound and periwound skin cleansing, debridement, wound edges refashioning, treatment, and dressing. ${ }^{2}$ However, although traditional dressings protect wounds from contamination and mechanical damage, they do not promote wound healing. In addition, dressing changes are often accompanied by damage of the regenerated wound surface and are associated with patient's pain. ${ }^{3}$ Ideally, a wound dressing should maintain moisture, absorb exudate, reduce pain, and be non-adherent, airy, sterile and antimicrobial. ${ }^{3}$ Recently, researchers have been focused on the properties and application of bacterial cellulose (BC). This biopolymer is applied in many industries, also in the medical field, and is considered to be one of the most promising wound dressing materials. ${ }^{4}$

The aim of this review was to discuss research focused on the physical properties of $\mathrm{BC}$ and the possibilities of its application in wound infection treatment.

\section{Properties of bacterial cellulose}

Bacterial cellulose is produced by various bacterial species, such as Rhizobium, Acetobacter, Sarcina, Pseudomonas, and Escherichia. ${ }^{5}$ Among them, Acetobacter xylinus spp., also named Gluconacetobacter xylinus spp. or Komagataeibacter xylinus spp., produces the most massive cellulose ribbon and is ubiquitous in BC production. ${ }^{6}$ Presumably, cellulose provides an extra bacterial matrix, expanding the colonization and offering the advantage in the nutrient competition. Furthermore, researchers postulate that cellulose protects bacteria from unfavorable environmental conditions. For instance, BC forming on the liquid-gas interface provides a constant access to the aerobic conditions. ${ }^{7}$

Bacterial cellulose microfibers are formed by $\beta-1,4-$ glucan chains resulting from the polymerization of uridine diphosphate glucose. Consequently, these microfibers aggregate into a fiber with a diameter from $10 \mathrm{~nm}$ to $100 \mathrm{~nm}$ and create a three-dimensional (3D) network with numerous pores due to hydrogen bonds. ${ }^{8}$ Although the molecular formula $\left(\mathrm{C}_{6} \mathrm{H}_{10} \mathrm{O}_{5}\right)_{\mathrm{n}}$ is the same for bacterial and plant cellulose, their physical and chemical features differ significantly. Contrary to plant cellulose, the BC microfibrils are 100 times thicker and form a reticular structure. Plant cellulose contains lignin, pectin and hemicellulose, while BC is free of such impurities. ${ }^{5}$ Due to its unique structure, it possesses high mechanical strength. Among its prominent features are $80-90 \%$ crystallinity, which, together with a high degree of polymerization (even up to $16,000 \mathrm{DPw}$ ), determines increased thermal stability and lower susceptibility to degradation. ${ }^{9}$ Bacterial cellulose displays good flexibility, permeability, hygroscopicity, and hydrophilicity. ${ }^{8}$ It is noteworthy that BC does not affect viability of fibroblasts and keratinocytes. ${ }^{10}$

There are 3 commonly applied BC production methods: static, agitation and bioreactor culture. In a static culture, $\mathrm{BC}$ film is produced on the gas-liquid interface in a span of 7-10 days and takes the shape of a flat gelatinous membrane. As a result of shaking, sphere-like or irregular cellulose shapes are formed. Agitation is intended to increase oxygen transport in the medium. However, according to the reports, shaking does not influence cellulose productivity. ${ }^{11}$ Moreover, physical properties of cellulose, such as crystallinity or the degree of polymerization obtained by the agitation method differ from the properties of $\mathrm{BC}$ obtained in a static culture. ${ }^{12}$ The bioreactor culture is applied in industrial bioreactors in order to reduce cultivation time and increase $\mathrm{BC}$ productivity. Bioreactors can be modified to provide various culture conditions such as oxygen-enriched air or rotating disks. ${ }^{13}$ Regardless of the method, after harvesting, BC is purified in sodium hydroxide from bacterial cell debris and substances in the culture medium, and washed with water to obtain a neutral $\mathrm{pH} .{ }^{12}$ Interestingly, it was reported that the properties of $\mathrm{BC}$ produced in a commercial HestrinSchramm (HS) medium are comparable to those of $\mathrm{BC}$ cultured in different media. Therefore, obtaining BC can be inexpensive and eco-friendly. ${ }^{14}$

\section{Bacterial cellulose as an antibacterial dressing}

Wound healing is a physiological process whose timing depends on the area and location of the injury. Unfortunately, therapeutic success may be delayed by several factors such as wound infection or an allergic reaction to the dressing. ${ }^{15,16}$ Wound infection may be caused by Gram-positive and Gram-negative bacteria or fungi, including multidrug-resistant strains. Therefore, the selection of an appropriate dressing is crucial to patient safety. ${ }^{15}$ Bacterial cellulose exhibits high biocompatibility and low cytotoxic effect, and does not induce allergic reactions. ${ }^{17}$ These properties promote the healing process and tissue regeneration. ${ }^{18}$ However, $\mathrm{BC}$ does not display antimicrobial properties. In order to impart antimicrobial properties to $\mathrm{BC}$, the researchers decided to take advantage of its absorbance and release potential and incorporate antimicrobial substances into the cellulose. ${ }^{19}$ 


\section{Metals}

Antibacterial activity of silver nanoparticles has been determined against Gram-positive and Gram-negative bacteria, but their mechanism of action is not well understood. It is speculated that silver ions inhibit bacterial growth by destroying the cell wall and repressing DNA transcription. ${ }^{20}$ Jalili Tabaii and Emtiazi prepared a cellulose carrier with silver nanoparticles by soaking $\mathrm{BC}$ in an $\mathrm{AgNO}_{3}$ solution. They reported that $\mathrm{BC}$ enriched with silver nanoparticles demonstrated an even 100\% higher antimicrobial effect against Staphylococcus aureus spp. and Escherichia coli spp. ${ }^{21}$ It was also reported that copper ions cause cell membrane damage and DNA impairment. ${ }^{22}$ Copper nanoparticles incorporated into BC displayed long-term bactericidal efficacy against $S$. aureus spp. and E. coli spp., for up to 90 days. ${ }^{23}$ Also, the antibacterial activity of $\mathrm{BC}$ chemisorbed with copper nanoparticles against Bacillus subtilis spp. and Candida albicans spp. was reported. ${ }^{24}$ It is worth noting that $\mathrm{BC}$ chemisorbed with copper nanoparticles did not exhibit cytotoxicity to fibroblasts. ${ }^{23}$ Additionally, BC chemisorbed with zinc oxide displayed antibacterial activity against $S$. aureus spp., Pseudomonas aeruginosa spp., and E. coli spp. ${ }^{25}$ Its antimicrobial mechanism of action relies on bacterial cell disruption, cell membrane hydrophobicity change and genes downregulation. Moreover, zinc oxide generates reactive oxygen species (ROS) that induce oxidative stress, leading to damage of the cell components. ${ }^{26}$ Additionally, zinc oxide incorporated in $\mathrm{BC}$ promotes wound healing and tissue regeneration. ${ }^{25}$

\section{Essential oils}

Recently, the antimicrobial action of essential oils (EOs) has been of interest to some researchers. ${ }^{27}$ Dudek-Wicher et al. studied the antibiofilm efficacy of 3 essential oils: tea tree, geranium and frankincense essential oils, incorporated in BC against Gram-positive (S. aureus spp., Enterococcus faecalis spp.) and Gram-negative (Klebsiella pneumoniae spp., P. aeruginosa spp., E. coli spp.) strains and 1 fungal strain (C. albicans spp.). All tested EOs exhibited antibiofilm efficacy against the tested strains, with efficacy of nearly $80-100 \%$, exhibited by tea tree and geranium essential oils. ${ }^{27}$ Unlike antiseptics or antibiotics, the volatile property of EOs allows them to reach the areas neighboring the areas of application. Bacterial cellulose enriched with thymol, a component of an essential oil, was successfully applied on a third-degree burn wound closure. Bacterial cellulose chemisorbed with thymol exhibited low cytotoxicity on fibroblasts and increased cell viability. ${ }^{28}$ Junka et al. tested 3 essential oils, namely clove, eucalyptus and thyme, against $S$. aureus spp. and P. aeruginosa spp..$^{10}$ All essential oils were successfully impregnated and effectively released from $\mathrm{BC}$ discs. Two different methods were applied to assess their antimicrobial activity. In the disk diffusion method, all tested EOs demonstrated very high efficacy. The $2^{\text {nd }}$ method (Antibiofilm Dressings Activity Measurement (ADAM)), considered the penetrability index of the tested EOs. This method has demonstrated significant differences in EO activity. Minor bactericidal activity was observed for clove oil, while thyme and eucalyptus oils displayed a significantly higher activity. However, thyme and clove oils displayed a significantly higher cytotoxicity against fibroblasts than the eucalyptus oil.

\section{Antibiotics}

The antibiotics most commonly applied in wound treatment are ceftriaxone, gentamycin, vancomycin, ciprofloxacin and tetracycline. Topical application of antibiotics in compresses previously immersed in an antibiotic solution is not recommended for wound infection treatment. ${ }^{29}$ The reasons are the difficulties in determining the drug concentration and the uncontrolled rate of drug release to the infected skin, which may increase the percentage of resistant strains. Antibiotic incorporation in $\mathrm{BC}$ makes it possible to determine the amount of the drug bound and to control the drug release rate from the membrane. ${ }^{30}$

Lazarini et al. compared the release time of ceftriaxone from BC produced in media with different sugar compositions. Bacterial cellulose produced in the medium supplemented with sugarcane molasses displayed a higher fiber density. ${ }^{31}$ Hence, the release time of ceftriaxone from chemisorbed $\mathrm{BC}$ was prolonged by $5 \mathrm{~h}$, as compared to $\mathrm{BC}$ cultured in a standard HS medium. ${ }^{31}$ Junka et al. successfully impregnated $\mathrm{BC}$ with gentamycin. The antibiotic concentration was $2 \mathrm{~g} / \mathrm{L}$, corresponding to the commercially available collagen gentamycin sponge. ${ }^{32}$ The release rate of gentamycin from $\mathrm{BC}$ was lower than from the collagen sponge. Even after $48 \mathrm{~h}$ of incubation, a small amount of gentamycin was released from BC. In contrast, $90 \%$ of gentamycin was released up to $8 \mathrm{~h}$ during the experiment from the collagen sponge. ${ }^{32}$ Bacterial cellulose dressings, chemisorbed with gentamicin in 2 concentrations of $2 \mathrm{~g} / \mathrm{L}$ and $0.006 \mathrm{~g} / \mathrm{L}$, were administered on rat bones. Despite their uneven and porous surface, $\mathrm{BC}$ chemisorbed with gentamycin effectively inhibited the growth of $S$. aureus spp., restraining the bacterial biofilm development. ${ }^{32}$ Furthermore, vancomycin and ciprofloxacin are widely applied in wound infection treatment. It was reported that $\mathrm{BC}$ dressings impregnated with these antibiotics effectively impede infection development. ${ }^{33} \mathrm{~A}$ high bactericidal effect of vancomycin and ciprofloxacin was determined against $S$. aureus spp. and K. pneumoniae spp. strains. Nevertheless, a significant amount of the antibiotics was released from $B C$ in the $1^{\text {st }}$ hour of the experiment. The above may lead to low usefulness of vancomycin and ciprofloxacin in $\mathrm{BC}$ in long-term wound treatment. ${ }^{33}$ However, Cacicedo et al. slowed the release rate of ciprofloxacin from $\mathrm{BC}$ by incorporating chitosan (Chi) into the cellulose structure. 
Bacterial cellulose/Chi modification prolonged the release time by more than $6 \mathrm{~h}$ and exhibited antimicrobial activity against $S$. aureus spp. and $P$. aeruginosa spp. Adding ciprofloxacin to the hybrid significantly enhanced the bactericidal effect. ${ }^{34}$ Shao et al. incorporated different tetracycline hydrochloride concentrations into $\mathrm{BC} .^{30}$ The lowest concentration of tetracycline hydrochloride in $\mathrm{BC}\left(0.41 \mathrm{mg} / \mathrm{dm}^{2}\right)$ was sufficient to restrain the growth of $S$. aureus spp., E. coli spp. and B. subtilis spp. However, the inhibition zone of $C$. albicans spp. was detectable only in the highest tested concentration $\left(10.17 \mathrm{mg} / \mathrm{dm}^{2}\right)$. The fast release stage of tetracycline was up to $1 \mathrm{~h}$ after the beginning of the experiment. Interestingly, the percentage of the antibiotics released from the cellulose was increased in the $\mathrm{BC} /$ tetracycline hydrochloride with higher concentrations of the incorporated antibiotic. Additionally, free tetracycline was released slower than when incorporated in $\mathrm{BC}$, which suggests the $\mathrm{BC}$ usefulness for controlled drug dosage. ${ }^{30}$

\section{Antiseptics and wound irrigation solutions}

In recent years, antiseptics have attracted considerable attention in wound care. The most commonly used wound healing agents include polyhexamethylene biguanide hydrochloride (PHMB), octenidine dihydrochloride (OCT), iodine povidone (PVP-I), and chlorhexidine gluconate (CHX). ${ }^{35,36}$ Their broad spectrum of action includes both Gram-positive and Gram-negative bacteria in vegetative and spore forms, as well as fungi, viruses and multidrug resistant strains. Most antiseptics are characterized by a high ability to eradicate the biofilm. Additionally, resistance mechanisms to these antimicrobials are not recorded. ${ }^{35}$

Dydak et al. presented the results of antimicrobial activity for all of the abovementioned antiseptics in the biocellulose disk diffusion method against Gram-positive (S. aureus spp., Staphylococcus epidermidis spp., Enterococcus faecium spp.), Gram-negative (K. pneumoniae spp., E. coli spp., Acinetobacter baumannii spp., P. aeruginosa spp., Enterobacter cloacae spp.) and fungal strains (C. albicans spp.). The most significant inhibition zones were found for PVP-I and CHX, followed by PHMB and OCT, against all tested bacteria. Also, the largest zone of inhibition of fungal strain growth was determined for PVP-I. Moreover, the high antifungal efficiency was shown for CHX and PHMB, whose inhibition zones were comparable. ${ }^{37} \mathrm{~W}$ iegand et al. reported that $\mathrm{PHMB}$ incorporated in $\mathrm{BC}$ exhibited a higher bactericidal activity against $S$. aureus spp. than PVP-I in BC. However, better biocompatibility in human keratinocytes was obtained for BC/PVP-I than for BC/PHMB. ${ }^{38}$ The BC/OCT displays a similar antimicrobial activity against $S$. aureus spp. and $P$. aeruginosa spp. Its high growth inhibitory efficacy was assessed using the disk diffusion method, in which the inhibition zones were $22-23 \mathrm{~mm}$ and $20-22 \mathrm{~mm}$, respectively. ${ }^{39}$ Also, Inoue et al. reported high inhibitory activity of $\mathrm{BC} / \mathrm{CHX}$ against $S$. aureus spp., E. coli spp. and C. albicans spp., using the disk diffusion method. ${ }^{40}$ Superoxidized hypochlorite solutions are considered wound irrigation solutions. However, there are reports of their very low efficacy in growth inhibition and biofilm eradication. ${ }^{41,42}$ The lack of antimicrobial efficacy of hydrochloride solutions has been demonstrated in microtiter plate studies and chemisorbed $\mathrm{BC} .{ }^{37,41-43}$ A wound irrigation product containing $0.004 \%$ of sodium hypochlorite and $0.004 \%$ of hypochlorite acid was evaluated in the research on the antimicrobial efficacy of antiseptics. ${ }^{37}$ No growth inhibition was detected with the disk diffusion method for most of the strains of the tested species of $S$. aureus spp., S. epidermidis spp., Enterococcus faecium spp., K. pneumoniae spp., E. coli spp., P. aeruginosa spp., E. cloacae spp., A. baumannii spp., and C. albicans spp.

The antimicrobial efficacy of antiseptics increases with prolonged real-contact time. ${ }^{44}$ The incorporation of antiseptics in $\mathrm{BC}$ makes it possible to extend the contact time of microorganisms exposed to antimicrobial agents. The insertion and release time depend on the molecular mass of the compound. ${ }^{38}$ As the molecular mass of the compound increases, the time of its release from the cellulose also increases. The PVP-I release from BC was slightly delayed compared to $\mathrm{PHMB}$, due to higher molecular mass of PVP-I. For both compounds, rapid release rate lasted up to $8 \mathrm{~h}$. Furthermore, release with a slower rate continued up to $24 \mathrm{~h}$ for PHMB and $48 \mathrm{~h}$ for PVP-I. ${ }^{38}$ The time of rapid release of octenidine was equal in the case for PHMB and PVP-I, the release with a slower rate continued even up to $96 \mathrm{~h} .{ }^{45}$ Moreover, 2 release stages of chlorhexidine from $\mathrm{BC}$ were observed by Inoue et al. The stage of rapid release took $15 \mathrm{~min}$ from the beginning of the experiment. After this time, the release rate slowed down and remained constant for $48 \mathrm{~h} .{ }^{40}$ The rapid release stage of 15 min was observed for PHMB and PVP-I by Krasowski et al. ${ }^{19}$ Octenidine incorporated in $\mathrm{BC}$ maintains its activity for an extended period. The BC/OCT stored for over 6 months presented similar features (low cytotoxicity and high antimicrobial activity) as a freshly prepared dressing. ${ }^{45}$ Alkhatib et al. supplemented BC with poloxamer to prolong OCT release time from BC. Poloxamer is a nonionic triblock copolymer which, when incorporated in $\mathrm{BC}$, does not affect the bactericidal efficacy of $\mathrm{BC} /$ OCT. Moreover, $\mathrm{BC} /$ poloxamer is highly biocompatible. The incorporation of poloxamer into $\mathrm{BC}$ enables extending the release time of OCT up to $8 \mathrm{~h}$ which can be employed for long-term treatment of chronic wounds. ${ }^{39}$

Additionally, incorporating antimicrobial substances into BC may influence the material structure, thus improving its physical properties. Adding PVP-I caused structural changes of $\mathrm{BC}$, which led to an increased comprehensive strength when compared to native $\mathrm{BC}$. In contrast, adding PHMB and OCT did not cause any changes in the cellulose structure. $^{38,45}$ 
Table 1. Effect of natural and synthetic polymers on selected physical properties of bacterial cellulose

\begin{tabular}{|c|c|c|c|c|}
\hline Parameter & Modification & $\begin{array}{l}\text { Value without } \\
\text { modification }\end{array}$ & Value with modification & Reference \\
\hline \multirow{4}{*}{$\begin{array}{c}\text { Temperature of thermal } \\
\text { degradation }\end{array}$} & bacterial cellulose/chitosan & $263^{\circ} \mathrm{C}$ & $366^{\circ} \mathrm{C}$ & 51 \\
\hline & bacterial cellulose/collagen & $262^{\circ} \mathrm{C}$ & $352^{\circ} \mathrm{C}$ & 53 \\
\hline & bacterial cellulose/polyacrylonitrile & $296^{\circ} \mathrm{C}$ & $560^{\circ} \mathrm{C}$ & 58 \\
\hline & bacterial cellulose/poly(ethylene glycol) & $263^{\circ} \mathrm{C}$ & $293^{\circ} \mathrm{C}$ & 59 \\
\hline \multirow[t]{3}{*}{ Young's modulus } & bacterial cellulose/chitosan & $6.0 \mathrm{GPa}$ & $1.8 \mathrm{GPa}$ & 51 \\
\hline & bacterial cellulose/collagen & $4.5 \mathrm{GPa}$ & $9.5 \mathrm{GPa}$ & 53 \\
\hline & bacterial cellulose/poly(ethylene glycol) & $6.35 \mathrm{GPa}$ & $4.12 \mathrm{GPa}$ & 59 \\
\hline
\end{tabular}

\section{Modifications of physical properties of bacterial cellulose in order to improve dressing design}

Bacterial cellulose exhibits excellent absorption properties. It consists of $99.9 \%$ water, which fills the pores formed by the nanofibrils structure. The pore size varies, depending on the cellulose culture time. As the culture time extends, the pore volume in the cellulose decreases, and thus, the surface area of the membrane is reduced. ${ }^{46}$ Poreforming agents added to the culture, such as agarose microparticles, can improve water holding capacity of $\mathrm{BC} .{ }^{47}$ Increased carrying capacity of $\mathrm{BC}$ and constant release of antibiotics from $\mathrm{BC}$ can also be obtained by changes in the culture medium carbon source. ${ }^{31}$ Also, laser piercing can be applied to enhance the amount of water trapping sites. ${ }^{48}$ The absorption ability of $\mathrm{BC}$ may involve exudate assimilation from the wound environment.

Bacterial cellulose can be functionalized with different natural and synthetic polymers to improve some of its mechanical properties. Chitosan is a biopolymer that adversely affects bacterial viability. ${ }^{49}$ Its mechanism of action relies on bonding to teichoic acids in the Gram-positive bacteria cell wall or disrupting the nutrients intake in Gram-negative strains. ${ }^{50} \mathrm{Cai}$ et al. reported that $\mathrm{BC}$ supplemented with chitosan (BC/Chi) showed enhanced thermal stability (temperature of thermal degradation increased from $263^{\circ} \mathrm{C}$ to $366^{\circ} \mathrm{C}$ ) and lower tensile strength (Young's modulus decreased from $6.0 \mathrm{GPa}$ to $1.8 \mathrm{GPa}$ ). ${ }^{51}$ One of the best-known natural polymers is collagen, whose drawbacks are high cost, poor mechanical properties and no antimicrobial effect. However, collagen is highly biodegradable and its surface offers excellent cell-binding properties. Therefore, collagen is studied as a scaffold for BC. ${ }^{52}$ Zhijiang and Guang reported that combining $\mathrm{BC}$ with collagen $(\mathrm{BC} / \mathrm{Col})$ increased thermal stability (temperature of thermal degradation changed from $262^{\circ} \mathrm{C}$ to $352^{\circ} \mathrm{C}$ ) and tensile strength (Young's modulus increased from $4.5 \mathrm{GPa}$ to $9.5 \mathrm{GPa}$ ), and decreased crystallinity (from $87 \%$ to $75 \%$ ). The $\mathrm{BC} / \mathrm{Col}$ scaffolds enabled fibroblasts to adhere and proliferate, contrary to native $\mathrm{BC}$, on which fibroblasts did not show enhanced growth after being adhered to the surface. ${ }^{53}$ Pasaribu et al. proposed a $\mathrm{BC}$ wound dressing functionalized with collagen and $\mathrm{Chi}$ in different configurations. ${ }^{54}$ The $\mathrm{BC} /$ $\mathrm{Col} / \mathrm{Chi}$ and $\mathrm{BC} / \mathrm{Chi} / \mathrm{Col}$ demonstrated similar moisture and antibacterial activity. However, $\mathrm{BC} / \mathrm{Chi} / \mathrm{Col}$ had smaller pores and displayed lower thermal stability than $\mathrm{BC} / \mathrm{Col} / \mathrm{Chi}$ (the temperatures of maximum mass-loss were $329^{\circ} \mathrm{C}$ and $338^{\circ} \mathrm{C}$, respectively). According to the report, a higher chitosan-to-collagen ratio in the dressing provides a better potential for wound dressing. Gelatine, a collagen denaturation product, is an alternative to collagen as a $\mathrm{BC}$ matrix. The $\mathrm{BC} /$ gelatine shows good adhesiveness and biocompatibility, promotes cell adhesion and is inexpensive.

Poly(acrylic acid), which inhibits bacterial growth, is among the synthetic polymers considered for incorporation into BC for wound dressing. ${ }^{55,56}$ Mohamad et al., who investigated burn wounds, reported significantly higher wound reduction in the group where $\mathrm{BC}$ with acrylic acid were enriched with fibroblasts and keratinocytes than in the control group including BC with acrylic acid only. Additionally, more significant collagen deposition was noted for BC loaded with cells, as compared with other treatments. ${ }^{57}$ Another example of synthetic polymer incorporated in $\mathrm{BC}$ is polyacrylonitrile. Xiao et al. reported that $\mathrm{BC} /$ polyacrylonitrile in 25:75 ratio displays higher thermal stability (temperature at weight losses of $50 \%$ increased from $296^{\circ} \mathrm{C}$ to $560^{\circ} \mathrm{C}$ ). Also, comparing dynamic contact angles, the $\mathrm{BC} /$ polyacrylonitrile composite has shown a high hygroscopicity property, playing a decisive role in exudate absorption. ${ }^{58} \mathrm{The} \mathrm{BC} /$ poly(ethylene glycol) composite was characterized by better adhesion and proliferation of fibroblast than pure BC. In addition, this polymer improved the thermal stability of $\mathrm{BC}$ (from $263^{\circ} \mathrm{C}$ to $293^{\circ} \mathrm{C}$ ), while tensile strength tended to decrease (Young's modulus decreased from 6.35 GPa to $4.12 \mathrm{GPa}){ }^{59}$

The effects of natural and synthetic polymers on selected physical properties of bacterial cellulose are presented in Table 1. 


\section{Other biomedical applications}

The research on the use of $\mathrm{BC}$ does not finish with the development of skin wound dressings. The usefulness of $\mathrm{BC}$ has been studied by scientists from various fields of medicine. Its high flexibility, persistence and good biocompatibility allow $\mathrm{BC}$ to conform to uneven surfaces and treat infections in hard-to-reach areas. There are reports of potential use of $\mathrm{BC}$ in dental therapies, treatment of inflammatory lesions, or after dental procedures, like extraction, root canal treatment or mucosal transplantation. ${ }^{19,60,61}$ Depending on the application, BC can be made stable or degradable, allowing it to be placed in the body permanently or temporarily. ${ }^{62}$ Some studies were carried out on the application of $\mathrm{BC}$ in bone engineering and cartilage implants. ${ }^{63,64}$ Due to the excellent biocompatibility and slow degradation, $\mathrm{BC}$ is considered a composite bone repair material. ${ }^{63}$ Moreover, $\mathrm{BC}$ coated with hydroxyapatite displays enhanced mechanical properties. ${ }^{63}$ It is excellently moldable, so that it can be applied in soft tissue reconstructions. It has frequently been reported that $\mathrm{BC}$ has potential to become a material for artificial blood vessels, for instance in replacement of atherosclerotic coronaries. ${ }^{64}$ Innovatively, Binnetoglu et al. applied $\mathrm{BC}$ tubes in facial nerve repairment, which allowed for robust myelinated fibers regeneration. ${ }^{65}$ An intriguing adaptation of BC was applied in eye therapeutics. Bacterial cellulose with convex shape can be used as contact lenses. Additionally, BC loaded with drugs may be applied in eyeball infections. ${ }^{66}$

\section{Conclusions}

Bacterial cellulose displays high absorption capacity, which makes it suitable for the incorporation of many antimicrobial substances, both hydrophilic and hydrophobic. Small molecules, such as metal ions, as well as high-molecular compounds with bactericidal activity, are being tested. Numerous studies have shown that antibiotics and antiseptics applied in wound infection treatment display high antimicrobial effect within release time from $B C$. Moreover, BC seems to be a proper carrier for essential oils that consist of antibacterial compounds and which may be used in wound care. Additionally, its physical properties such as crystallinity, thermal stability and tensile strength can be easily modified by specific changes implemented in a culture method or incorporation of natural or synthetic polymers. The aforementioned advantages of $\mathrm{BC}$ make it a promising material for wound dressing development.

\section{ORCID iDs}

Justyna Paleczny (D) https://orcid.org/0000-0002-8783-7123 Malwina Brożyna (D) https://orcid.org/0000-0001-9520-3377 Adam Junka (i) https://orcid.org/0000-0002-7559-8903 Marzenna Bartoszewicz (D) https://orcid.org/0000-0002-6542-2525 Ruth Karolina Dudek-Wicher (D) https://orcid.org/0000-0001-8033-3531

\section{References}

1. Sen CK, Gordillo GM, Roy S, et al. Human skin wounds: A major and snowballing threat to public health and the economy. Wound Repair Regen. 2009;17(6):763-771. doi:10.1111/j.1524-475X.2009.00543.x

2. Murphy C, Atkin L, Dissemond J, et al. Defying hard-to-heal wounds with an early antibiofilm intervention strategy: 'Wound hygiene.' J Wound Care. 2019;28(12):818-822. doi:10.12968/jowc.2019.28.12.818

3. Broussard KC, Powers JG. Wound dressings: Selecting the most appropriate type. Am JClin Dermatol. 2013;14(6):449-459. doi:10.1007/s40257013-0046-4

4. Zhong C. Industrial-scale production and applications of bacterial cellulose. Front Bioeng Biotechnol. 2020;8:605374. doi:10.3389/fbioe. 2020.605374

5. Shoda M, Sugano Y. Recent advances in bacterial cellulose production. Biotechnol Bioprocess Eng. 2005;10(1):1-8. doi:10.1007/ BF02931175

6. Rehm B. Microbial production of biopolymers and polymer precursors. Caister Academic; 2009. https://agris.fao.org/agris-search/ search.do?recordID=US201300132373. Accessed June 25, 2021.

7. Williams WS, Cannon RE. Alternative environmental roles for cellulose produced by acetobacter xylinum. Appl Environ Microbiol. 1989; 55(10):2448-2452. doi:10.1128/aem.55.10.2448-2452.1989

8. Grande CJ, Torres FG, Gomez CM, Troncoso OP, Canet-Ferrer J, MartínezPastor J. Development of self-assembled bacterial cellulose-starch nanocomposites. Mater SciEng C. 2009;29(4):1098-1104. doi:10.1016/ j.msec.2008.09.024

9. van Zyl EM, Coburn JM. Hierarchical structure of bacterial-derived cellulose and its impact on biomedical applications. Curr Opin Chem Eng. 2019;24:122-130. doi:10.1016/j.coche.2019.04.005

10. Junka A, Żywicka A, Chodaczek G, et al. Potential of biocellulose carrier impregnated with essential oils to fight against biofilms formed on hydroxyapatite. Sci Rep. 2019;9(1):1256. doi:10.1038/s41598-01837628-x

11. Rodrigues AC, Fontão Al, Coelho A, et al. Response surface statistical optimization of bacterial nanocellulose fermentation in static culture using a low-cost medium. N Biotechnol. 2019;49:19-27. doi:10.1016/j. nbt.2018.12.002

12. Czaja W, Romanovicz D, Brown RM. Structural investigations of microbial cellulose produced in stationary and agitated culture. Cellulose. 2004;11(3):403-411. doi:10.1023/B:CELL.0000046412.11983.61

13. Wang J, Tavakoli J, Tang Y. Bacterial cellulose production, properties and applications with different culture methods: A review. CarbohydrPolym. 2019;219:63-76. doi:10.1016/j.carbpol.2019.05.008

14. Revin V, Liyaskina E, Nazarkina M, Bogatyreva A, Shchankin M. Costeffective production of bacterial cellulose using acidic food industry by-products. Braz J Microbiol. 2018;49(Suppl 1):151-159. doi:10.1016/j. bjm.2017.12.012

15. Guo S, DiPietro LA. Factors affecting wound healing. J Dent Res. 2010; 89(3):219-229. doi:10.1177/0022034509359125

16. Metcalf DG, Bowler PG. Biofilm delays wound healing: A review of the evidence. Burns Trauma. 2013;1(1):5-12. doi:10.4103/2321-3868.113329

17. Salamat-Miller N, Chittchang M, Johnston TP. The use of mucoadhesive polymers in buccal drug delivery. Adv Drug Deliv Rev. 2005; 57(11):1666-1691. doi:10.1016/j.addr.2005.07.003

18. Khan S, Ul-Islam M, Ikram M, et al. Preparation and structural characterization of surface modified microporous bacterial cellulose scaffolds: A potential material for skin regeneration applications in vitro and in vivo. Int J Biol Macromol. 2018;117:1200-1210. doi:10.1016/j. ijbiomac.2018.06.044

19. Krasowski G, Wicher-Dudek R, Paleczny J, et al. Potential of novel bacterial cellulose dressings chemisorbed with antiseptics for the treatment of oral biofilm infections. App/Sci. 2019;9(24):5321. doi:10.3390/ app9245321

20. Le Ouay B, Stellacci F. Antibacterial activity of silver nanoparticles: A surface science insight. Nano Today. 2015;10(3):339-354. doi:10. 1016/j.nantod.2015.04.002

21. Jalili Tabaii M, Emtiazi G. Transparent nontoxic antibacterial wound dressing based on silver nano particle/bacterial cellulose nano composite synthesized in the presence of tripolyphosphate. J Drug Deliv Sci Technol. 2018;44:244-253. doi:10.1016/j.jddst.2017.12.019

22. Bogdanović U, Lazić V, Vodnik V, Budimir M, Marković Z, Dimitrijević S. Copper nanoparticles with high antimicrobial activity. Mater Lett. 2014;128:75-78. doi:10.1016/j.matlet.2014.04.106 
23. He W, Huang X, Zheng Y, et al. In situ synthesis of bacterial cellulose/ copper nanoparticles composite membranes with long-term antibacterial property. J Biomater Sci Polym Ed. 2018;29(17):2137-2153. doi:10.1080/09205063.2018.1528518

24. Shao W, Wang S, Wu J, Huang M, Liu H, Min H. Synthesis and antimicrobial activity of copper nanoparticle loaded regenerated bacterial cellulose membranes. RSCAdv. 2016;6(70):65879-65884. doi:10.1039/ C6RA07984A

25. Khalid A, Khan R, Ul-Islam M, Khan T, Wahid F. Bacterial cellulose-zinc oxide nanocomposites as a novel dressing system for burn wounds. Carbohydr Polym. 2017;164:214-221.doi:10.1016/j.carbpol.2017.01.061

26. Pati R, Mehta RK, Mohanty S, et al. Topical application of zinc oxide nanoparticles reduces bacterial skin infection in mice and exhibits antibacterial activity by inducing oxidative stress response and cell membrane disintegration in macrophages. Nanomedicine. 2014;10(6): 1195-1208. doi:10.1016/j.nano.2014.02.012

27. Dudek-Wicher R, Paleczny J, Kowalska-Krochmal B, et al. Activity of liquid and volatile fractions of essential oils against biofilm formed by selected reference strains on polystyrene and hydroxyapatite surfaces. Pathogens. 2021;10(5):515. doi:10.3390/pathogens10050515

28. Jiji S, Udhayakumar S, Rose C, Muralidharan C, Kadirvelu K. Thymo enriched bacterial cellulose hydrogel as effective material for third degree burn wound repair. Int J Biol Macromol. 2019;122:452-460. doi:10.1016/j.ijbiomac.2018.10.192

29. Lipsky BA, Hoey C. Topical antimicrobial therapy for treating chronic wounds. Clin Infect Dis. 2009;49(10):1541-1549. doi:10.1086/644732

30. Shao W, Liu H, Wang S, et al. Controlled release and antibacterial activity of tetracycline hydrochloride-loaded bacterial cellulose composite membranes. Carbohydr Polym. 2016;145:114-120. doi:10.1016/j. carbpol.2016.02.065

31. Lazarini SC, de Aquino R, Amaral AC, et al. Characterization of bilayer bacterial cellulose membranes with different fiber densities: A promising system for controlled release of the antibiotic ceftriaxone. Cellulose. 2016;23(1):737-748. doi:10.1007/s10570-015-0843-4

32. Junka A, Bartoszewicz M, Dziadas $M$, et al. Application of bacterial cellulose experimental dressings saturated with gentamycin for management of bone biofilm in vitro and ex vivo. J Biomed Mater Res B Appl Biomater. 2020;108(1):30-37. doi:10.1002/jbm.b.34362

33. Vismara $E$, Bernardi $A$, Bongio $C$, et al. Bacterial nanocellulose and its surface modification by glycidyl methacrylate and ethylene glycol dimethacrylate: Incorporation of vancomycin and ciprofloxacin. Nanomaterials (Basel). 2019;9(12):1668. doi:10.3390/nano9121668

34. Cacicedo ML, Pacheco G, Islan GA, Alvarez VA, Barud HS, Castro GR Chitosan-bacterial cellulose patch of ciprofloxacin for wound dressing: Preparation and characterization studies. Int J Biol Macromol. 2020;147:1136-1145. doi:10.1016/j.ijbiomac.2019.10.082

35. Kramer A, Dissemond J, Kim S, et al. Consensus on wound antisepsis: Update 2018. Skin Pharmacol Physiol. 2018;31(1):28-58. doi:10.1159/ 000481545

36. Murphy C, Atkin L, Swanson T, et al. Defying hard-to-heal wounds with an early antibiofilm intervention strategy: Wound hygiene. J Wound Care. 2020;29(Sup3b):S1-S26. doi:10.12968/jowc.2020.29.Sup3b.S1

37. Dydak K, Junka A, Dydak A, et al. In vitro efficacy of bacterial cellulose dressings chemisorbed with antiseptics against biofilm formed by pathogens isolated from chronic wounds. Int J Mol Sci. 2021;22(8): 3996. doi:10.3390/ijms22083996

38. Wiegand C, Moritz S, Hessler N, et al. Antimicrobial functionalization of bacterial nanocellulose by loading with polihexanide and povidone-iodine. J Mater Sci Mater Med. 2015;26(10):245. doi:10.1007/ s10856-015-5571-7

39. Alkhatib Y, Dewaldt M, Moritz S, Nitzsche R, Kralisch D, Fischer D. Controlled extended octenidine release from a bacterial nanocellulose/ Poloxamer hybrid system. Eur J Pharm Biopharm. 2017;112:164-176. doi:10.1016/j.ejpb.2016.11.025

40. Inoue BS, Streit S, Dos Santos Schneider AL, Meier MM. Bioactive bacterial cellulose membrane with prolonged release of chlorhexidine for dental medical application. Int J Biol Macromol. 2020;148: 1098-1108. doi:10.1016/j.ijbiomac.2020.01.036

41. Severing AL, Rembe JD, Koester V, Stuermer EK. Safety and efficacy profiles of different commercial sodium hypochlorite/hypochlorous acid solutions ( $\mathrm{NaClO} / \mathrm{HClO})$ : Antimicrobial efficacy, cytotoxic impact and physicochemical parameters in vitro. J Antimicrob Chemother. 2019;74(2):365-372. doi:10.1093/jac/dky432
42. Rembe JD, Huelsboemer L, Plattfaut I, Besser M, Stuermer EK. Antimicrobial hypochlorous wound irrigation solutions demonstrate lower anti-biofilm efficacy against bacterial biofilm in a complex invitro human plasma biofilm model (hpBIOM) than common wound antimicrobials. Front Microbiol. 2020;11:564513. doi:10.3389/fmicb. 2020.564513

43. Krasowski G, Junka A, Paleczny J, et al. In vitro evaluation of polihexanide, octenidine and $\mathrm{NaClO} / \mathrm{HClO}$-based antiseptics against biofilm formed by wound pathogens. Membranes (Basel). 2021;11(1):62. doi:10.3390/membranes11010062

44. Junka A, Bartoszewicz M, Smutnicka D, Secewicz A, Szymczyk P. Efficacy of antiseptics containing povidone-iodine, octenidine dihydrochloride and ethacridine lactate against biofilm formed by Pseudomonas aeruginosa and Staphylococcus aureus measured with the novel biofilm-oriented antiseptics test. Int Wound J. 2014;11(6): 730-734. doi:10.1111/iwj.12057

45. Moritz S, Wiegand C, Wesarg F, et al. Active wound dressings based on bacterial nanocellulose as drug delivery system for octenidine. Int J Pharm. 2014;471(1-2):45-55. doi:10.1016/j.ijpharm.2014.04.062

46. Żywicka A, Wenelska K, Junka A, Chodaczek G, SzymczykP, Fijałkowski K. Immobilization pattern of morphologically different microorganisms on bacterial cellulose membranes. World J Microbiol Biotechnol. 2019;35(1):11. doi:10.1007/s11274-018-2584-7

47. Yin N, Stilwell MD, Santos TMA, Wang H, Weibel DB. Agarose particle-templated porous bacterial cellulose and its application in cartilage growth in vitro. Acta Biomater. 2015;12:129-138. doi:10.1016/j. actbio.2014.10.019

48. Horbert V, Boettcher J, Foehr P, et al. Laser perforation and cell seeding improve bacterial nanocellulose as a potential cartilage implant in the in vitro cartilage punch model. Cellulose. 2019;26(1):647-664. doi:10.1007/s10570-019-02286-3

49. Michalska-Sionkowska M, Walczak M, Sionkowska A. Antimicrobial activity of collagen material with thymol addition for potential application as wound dressing. Polym Test. 2017;63:360-366. doi:10.1016/j. polymertesting.2017.08.036

50. Verlee A, Mincke S, Stevens CV. Recent developments in antibacterial and antifungal chitosan and its derivatives. Carbohydr Polym. 2017;164:268-283. doi:10.1016/j.carbpol.2017.02.001

51. Cai Z, Chen P, Jin HJ, Kim J. The effect of chitosan content on the crystallinity, thermal stability, and mechanical properties of bacterial celIulose-chitosan composites. Proc Inst Mech Eng Part C J Mech Eng Sci. 2009;223(10):2225-2230. doi:10.1243/09544062JMES1480

52. Torres FG, Commeaux S, Troncoso OP. Biocompatibility of bacterial cellulose based biomaterials. J Funct Biomater. 2012;3(4):864-878. doi:10.3390/jfb3040864

53. Zhijiang C, Guang Y. Bacterial cellulose/collagen composite: Characterization and first evaluation of cytocompatibility. J Appl Polym Sci. 2011;120(5):2938-2944. doi:10.1002/app.33318

54. Pasaribu KM, Gea S, Ilyas S, Tamrin T, Radecka I. Characterization of bacterial cellulose-based wound dressing in different order impregnation of chitosan and collagen. Biomolecules. 2020;10(11):1511. doi:10. 3390/biom10111511

55. Ni Z, Wang Z, Sun L, Li B, Zhao Y. Synthesis of poly acrylic acid modified silver nanoparticles and their antimicrobial activities. Mater Sci Eng CMater Biol Appl. 2014;41:249-254. doi:10.1016/j.msec.2014.04.059

56. Chuah C, Wang J, Tavakoli J, Tang Y. Novel bacterial cellulose-poly (acrylic acid) hybrid hydrogels with controllable antimicrobial ability as dressings for chronic wounds. Polymers (Basel). 2018;10(12):1323. doi:10.3390/polym10121323

57. Mohamad $\mathrm{N}$, Loh EYX, Fauzi MB, Ng MH, Mohd Amin $\mathrm{MCl}$. In vivo evaluation of bacterial cellulose/acrylic acid wound dressing hydrogel containing keratinocytes and fibroblasts for burn wounds. Drug Deliv Transl Res. 2019;9(2):444-452. doi:10.1007/s13346-017-0475-3

58. Xiao Y, Cao Y, Liu Y, et al. Electrospun natural cellulose/polyacrylonitrile nanofiber: Simulation and experimental study. Text Res J. 2019;89(9):1748-1758. doi:10.1177/0040517518779256

59. Cai Z, Kim J. Bacterial cellulose/poly(ethylene glycol) composite: Characterization and first evaluation of biocompatibility. Cellulose. 2010;17(1):83-91. doi:10.1007/s10570-009-9362-5

60. Weyell P, Beekmann U, Küpper C, et al. Tailor-made material characteristics of bacterial cellulose for drug delivery applications in dentistry. Carbohydr Polym. 2019;207:1-10. doi:10.1016/j.carbpol. 2018.11.061 
61. Yoshino A, Tabuchi M, Uo M, et al. Applicability of bacterial cellulose as an alternative to paper points in endodontic treatment. Acta Biomater. 2013;9(4):6116-6122. doi:10.1016/j.actbio.2012.12.022

62. Torgbo S, Sukyai P. Biodegradation and thermal stability of bacterial cellulose as biomaterial: The relevance in biomedical applications. Polym Degrad Stab. 2020;179:109232. doi:10.1016/j.polymdegradstab. 2020.109232

63. Gutiérrez-Hernández JM, Escobar-García DM, Escalante A, et al. In vitro evaluation of osteoblastic cells on bacterial cellulose modified with multi-walled carbon nanotubes as scaffold for bone regeneration. Mater SciEng CMaterBiolAppl.2017;75:445-453. doi:10.1016/j.msec.2017.02.074
64. Klemm D, Schumann D, Udhardt U, Marsch S. Bacterial synthesized cellulose: Artificial blood vessels for microsurgery. Prog Polym Sci. 2001;26(9):1561-1603. doi:10.1016/S0079-6700(01)00021-1

65. Binnetoglu A, Demir B, Akakin D, Kervancioglu Demirci E, Batman C. Bacterial cellulose tubes as a nerve conduit for repairing complete facial nerve transection in a rat model. Eur Arch Otorhinolaryngol. 2020;277(1):277-283. doi:10.1007/s00405-019-05637-9

66. Coelho F, do Vale Braido GV, Cavicchioli M, et al. Toxicity of therapeutic contact lenses based on bacterial cellulose with coatings to provide transparency. Contact Lens Anterior Eye. 2019;42(5):512-519. doi:10.1016/j.clae.2019.03.006 